\title{
Problems and Countermeasures of Indian Women Entrepreneurs' Entrepreneurship Development
}

\author{
Dr. R Jawahar Babu ${ }^{1}$, Dr. S. Lakshmi ${ }^{2}$, Dr. M Manjula ${ }^{3}$ \\ ${ }^{1}$ Assistant Professor LIS, PG \& Research Department of Library and Information Science, Srimad Andavan Arts and Science College \\ (Autonomous), Tiruchirapalli 620005 \\ rtjbabu@gmail.com \\ ${ }^{2}$ Associate Professor LIS, PG \& Research Department of Library and Information Science, Srimad Andavan Arts and Science College
(Autonomous), Tiruchirapalli 620005 \\ ${ }^{3}$ Assistant Professor LIS, PG \& Research Department of Library and Information Science, Srimad Andavan Arts and Science College \\ (Autonomous), Tiruchirapalli 620005
}

\begin{abstract}
Women are generally called home makers. They care family and children in good care. They were less participated in the economy. In this topic women entrepreneurship has been ill treated both the society and family. Entrepreneurship is the core of economic development. Women is the key factor of entrepreneurship. In present time women are the emerging economic force. Social and economic development of women is necessary for the development of our mother country. Due to the changing environment women entrepreneur increasing the service sector. The purpose of this study was to find out the problem focused on women entrepreneurship. It will also suggest the practical problem and possible solutions to the women entrepreneurship.
\end{abstract}

Keywords: women entrepreneur, problems, solutions, Decision Making, Equality

\section{Introduction}

Women in India: In our society set up male are dominated one. Women are considered as "Shakthi" in India, but she is also called weaker sex and always depend on men and their family members outside throughout their life. Each and every time she take a decision depending upon their family men. It is our culture as well as our family structure. The women is taking care of their children and parents with love and care. The traditional set up changing in modern India transform educational status of women for better living. It is time to change in the life style of Indian women both in urban as well as in rural areas.

- Women is considered Nari Shakthi mean source of power.

- She will manage the available resources in a perfect manner.

- Efficient execution and decision making.

- Clear vision to take care the welfare of children and family.

- Patient and helpful to others.

- Ability to do work in all ages.

\section{Women Entrepreneurship}

A person who accept challenging role to meet her personal needs and become economically independent. She is capable to contribute both family and society. They contribute family significantly to the running family business mostly in the form of unpaid effort and very little skills. The value of the women is underestimated both the families taking granding the academic studies. Federation of Indian Women Entrepreneurs (FIWE), which is the national level organization having large membership of 15000 active individual members and professionals and more than 28 member association spread throughout the country. The main objective is the organization is to faster the economic empowerment of women. It provides the networking platform for the entrepreneur women. It the remodel the shape of skill development and training creates the business women.

\section{Review of Literature}

Norlia Ahmed Kassim (2010) Information needs of Malaysian Bumi - petura would be entrepreneurs; Malaysian Journal of Library and Information Science Vol (15) No.2: This study has provided information on the information needs of would - be entrepreneurs and it is hoped that findings from this study would provide an understanding of the information needs of potential and novice entrepreneurs

Peter Underwood (2009) Supporting the information needs of entrepreneurs in South Africa. International Library Review.58 (8): This study elucidates that concentration on increasing capacity at the point of delivery of information through knowledge of business environment and information literacy is essential.

Robert Ikoja - Odongo (2004) Information seeking behaviour of the informal sector entrepreneurs: The Uganda experience. Libri Vol 54 ISSN: 0024 - 2667 This study suggest that modern/exotic models of information transfer based on textual media and ICT exhibit less impact on the entrepreneurs' information needs and use at macro levels because of poverty, illiteracy and poor information infrastructure. The study concludes that an appropriate model for information behaviour for the information poor community must be grounded on oral traditions and indigenous knowledge and be sensitive to poverty, infrastructure and illiteracy. 


\section{Good quality of Entrepreneur}

- Innovative Thinking

- Positivity

- Quick and effective decision making

- Self confident

- Accept the risk

- Changes are adapting at the right time.

- Always alert the latest scientific and technical information.

Most of the women have these qualities, but they never got a platform to show their talents and abilities. The potential women are recognized and exposed for the service sector for the development of the nation.

\section{Problems faced on women Entrepreneurship}

\subsection{Gender}

India is male dominated traditional society. Women are treated as physically weak and lesser confidence.

\subsection{Less education}

Most of the women are lagging far behind the field of education. 60 percent of the women are illiterate. Due to lack of proper education, poverty and early marriage. They do not know the new technology, new methods of production, marketing and other governmental support and encourage to shine.

\subsection{Problem of finance}

Women entrepreneurs suffer a lot in raising and meeting the financial needs of the business. Bankers are not forward to provide financial status of women and more chances of failure.

\subsection{Lack of technology}

Women entrepreneur face the lack of technology knowledge. Their slow adoption of changing technology is the major factor of affecting the high cost of production.

\subsection{Risk taking capacity}

The women are naturally very sigh and soft in character. Lack of education and training they are not taken risk in the involved an enterprises.

\subsection{Less entrepreneurial aptitude}

Less entrepreneurial aptitude is a matter for the women entrepreneurs. Even they attending various training programs on entrepreneurship they failed to tide over the risk and troubles of the organizations.

\subsection{Less Managerial skills}

Women are less in managerial function like planning, organizing, controlling, coordination and budgeting. This is the problem to run the business in success.

\subsection{Legal formalities}

Fulfilling the legal formalities required for running an enterprise they face the corrupt practices in government offices and procedural delays for various licenses like electricity, and water and environment. They face very hard to handle the situation.

\subsection{Little self confidence}

Women entrepreneurs face the very big problem to handle the balance between a family and managing an enterprise. In this situation she women lacks self confidence. Additionally the tradition and customs, social cultural values, ethics, motherhood, physically weakness, hard work areas, feeling of insecurity, are some peculiar problems that the Indian women are coming across while they jump into entrepreneurship.

\section{Possible Solutions}

- Proper training in a right time in a right planned manner and execute in all the required levels.

- Identify the women in different educational level in proper groups and to create awareness to all the required levels

- Create awareness in business and entrepreneurship and its importance as job providing avenues and job seeking avenues.

- Expected skills to be provided to selected women and self help groups are to be identified.

- Create awareness and to making them to realize the income generation and social status and recognition

- Giving orientation and skill training on selected trades, of their choice and suitability,

- Assisting them in preparation of project reports for their own proposed units and helping them to follow up the venture to start the new enterprise

\section{Training Component}

Regional level programmes at the residential area of women in their vernacular language and to specific requirement of the people in their area were conducted by reputed national level institutions like EDI Ahmedabad, NSTED Board New Delhi, and State level institutions like CED in Madurai and Chennai.

The main motto of the programmes;

- Awareness, career building and to change enterprise formation.

- Effective training on self - confidence and communication skills.

- Skill training on specific trades suitable to their own option.

- Training on effective decision making techniques and managerial skills.

- Training on marketing strategies and techniques.

- Training on effective financial management techniques. 
- Training on research project formulation and implementation.

- Training for increasing access to new technologies and scientific knowledge.

- Interaction with successful women entrepreneurs for sharing their experiences to success.

Training in such areas are not going to have much financial burden to the govt., when compared to other developmental projects. This type of programs can be conducted regularly and compulsory to attend the women entrepreneur in all parts of the country.

\section{Conclusion}

In our society set up has been traditionally a male dominated one. This traditional set up is changing in the modern era. The transformation of women entrepreneur ship of the Indian society, in terms of increased the status of educational and culture. Indian women are the privilege in India. The entrepreneur women taking more responsibilities and challenges to meet a better lifestyle. They need lots of motivation and encouragement to peers and government. They expect the moral support from the families and financial support from the banking sector. These are the some ways to improve the women self confidence and managerial skills.

\section{References}

[1] Das, M. (2000). Women entrepreneurs from India: Problems, motivations and success factors. Journal of Small Business \& Entrepreneurship, 15 (4), 67 - 81.

[2] Bruni, A., Gherardi, S., \& Poggio, B. (2004). Entrepreneur-mentality, gender and the study of women entrepreneurs. Journal of organizational change management.

[3] Siddiqui, A. B. (2012). Problems encountered by women entrepreneurs in India. International Journal of Applied Research \& Studies, 1 (2), 01 - 11.

[4] Kaushik, S. (2013). Challenges faced by women entrepreneurs in India. Education, 35 (53), 53.

[5] Singh, A. (2014). Role of women entrepreneurs in India: A SWOT analysis. International Journal of Management and International Business Studies, 4 (2), $231-238$

[6] Mathew, R. V., \& Panchanatham, N. (2011). An exploratory study on the work - life balance of women entrepreneurs in South India. Asian academy of management journal, 16 (2).

[7] Ahl, H. (2006). Why research on women entrepreneurs needs new directions. Entrepreneurship theory and practice, 30 (5), 595 - 621.

[8] Dhameja, S. K. (2002). Women Entrepreneurs: Opportunities, performance and problems. Deep and Deep Publications.

[9] Priyadarshini, S., \& Basariya, S. R. (2018). Women Entrepreneurs - Problems and Prospects in India. International Journal of Civil Engineering and Technology (IJCIET), 9 (4), 96 - 102.

[10] Manjula M (2019) Scientometric Analysis of violence against women publications: A study based on web of science database. International journal of scientific research and review, 8 (2).2279 - 543X P196 - 207 